\title{
The Entrepreneurial Orientation and the Organizational Performance: Do Enterprise Resource Planning Systems Have a Mediating Role? A Study on Dubai Police
}

\author{
Hassan Saleh Al-Dhaafri ${ }^{1}$ \& Abdullah Kaid Al-Swidi ${ }^{2}$ \\ ${ }^{1}$ Dubai Police, Dubai, United Arab Emirates, Othman Yeop Abdullah Graduate School of Business, University \\ Utara Malaysia, Malaysia \\ ${ }^{2}$ Othman Yeop Abdullah Graduate School of Business, University Utara Malaysia, Sintok, Malaysia \\ Correspondence: Abdullah Kaid Al-Swidi, Othman Yeop Abdullah Graduate School of Business, University \\ Utara Malaysia, Sintok, Malaysia. Tel: 60-12-466-2754. E-mail: swidi@uum.edu.my
}

Received: September 24, 2013 Accepted: November 2, $2013 \quad$ Online Published: December 29, 2013

doi:10.5539/ass.v10n2p257

URL: http://dx.doi.org/10.5539/ass.v10n2p257

\begin{abstract}
Purpose: This study was set up to examine the mediating role of ERP system on the relationship between entrepreneurial orientation and organizational performance.

Design/methodology/approach: To examine the hypothesized model developed for this study, the survey quantitative research design was employed. For that, the data were collected from Dubai police departments. Out of 150 questionnaires distributed, 111 usable questionnaires were returned. Employing the partial least squares structural equation modeling for data analysis.

Findings: Based on the statistical results, the effect of entrepreneurial orientation and enterprise resource planning on organizational performance were confirmed. In addition, ERP was found to partially mediate the effect of EO on organizational performance. Further details and valuable implications of this study were discussed throughout the study.

Practical implications: The results of this study have many practical implications. The results will help managers to take the proper decision when deciding to implement ERP system in their organizations. The ERP can help managers with strong EO to achieve the maximum performance in organizations and to remain competitive in the market.
\end{abstract}

Originality/value: This study is considered one of the very few empirical studies that examine the effect of EO on ERP and the mediating effect of ERP on the EO-performance relationship.

Keywords: entrepreneurial orientation (EO), enterprise resource planning (ERP), organizational performance (OP), Dubai police (DP), paper type research paper

\section{Introduction}

Nowadays, organizations around the world need information technology (IT) to improve the flow of information across the whole organization, streamline business processes, establish linkages with supplier, reduce costs, offer product variety, and reduce the time response to customer to meet their expectations and needs (Beheshti, 2006). Because of the huge volume of data obtained by any business organization, it is very important to have an integrated system that can help organizations in managing and organizing data to be ready for use by decision makers (Al-Dhaafri, Yusoff, \& Al-Swidi, 2013). They added that Enterprise Resource Planning (ERP) systems have been acquiring a growing importance and popularity as a significant source for achieving organizational performance. Davenport (1998) reported that ERP systems are considered as the most significant development in the corporate information technology; as one the most innovation in technology in the last two decades (Jha \& Joshi, 2007).

ERP systems have been widely used in the developed countries either in public or private sectors. However, the investment in ERP systems in developing countries is still in its early phase for different reasons (Huang \& Palvia, 2001). It has been found by many researchers that there are conflicting results regarding the relationship between ERP and organizational performance. While some of them confirmed the added value to organizations 
when employing ERP systems (Davenport \& Brooks, 2004; Irani \& Love, 2001), other researchers found that ERP may have a negative impact on performance (Hunton, Lippincott, \& Reck, 2003; Velcu, 2007).

To face today's business challenges, entrepreneurship has become an important concept to sustain competitive advantages, acquire successfulness, and increase organizational performance (Covin \& Slevin, 1986). Entrepreneurial orientation in the entrepreneurship literature has several definitions. One of them has been defined by Zahra and Covin (1995) where they defined EO as the potential instrument for inspiration established organizations to gain high performance through innovation, risk-taking, and proactiveness. These three dimensions of EO have been suggested earlier by many writers such as Miller (1983), and later Lumpkin and Dess (1996) added aggressiveness and autonomy. However, the majority of the researchers used the three dimensions to measure EO, namely, innovativeness, proactiveness, and risk-taking (Wiklund, 1999). The relationship between EO and organizational performance has been studied by many writers. However, some of them reported that EO has a positive relationship with organizational performance (Jogaratnam \& Tse, 2006; Lee, Lim, \& Pathak, 2011), others found an adverse result (Li, Zhang, \& Chan, 2005; Smart \& Conant, 1994). Therefore, the previous conflicting results require further studies and investigation to explore the reasons behind this conflicting and what mechanism can explain the relationship better to have positive results.

For this purpose, Enterprise Resource Planning (ERP) has been intervened between EO and organizational performance to explain the mechanism and role of ERP in achieving EO benefit to increase organizational performance. Organizational investment in technology in general and ERP in particular is not an easy task due to its complex, problematic, costly, high rate of failure, lack of fit to business, and culture. The role of leadership and entrepreneurial decisions are very important to have a step to implement ERP systems in the organization. The first problem faces organization is the daring decision to have ERP system or not.

In this study, we examine the relationship between EO and organizational performance with the existence of ERP as a mediating variable to explain the mechanism in which EO can affect organizational performance. Dubai Police has been taken in this study as a context to examine the relationships between variables. The reasons behind selecting Dubai Police is that it has used an ERP system from Oracle since 10 years, therefore the questionnaire survey will be distributed among Dubai Police officers.

\section{Related Literature and Research Hypotheses}

Enterprise resource planning (ERP) is regarded as one of the most technological and organizational changes in the last two decades that help to increase productivity and efficiency, however, investment in ERP systems is not an easy task for some reasons such as implementation difficulties, high associated cost, intensive training needed, supplier cooperation, and others. Therefore, the entrepreneurial orientation and keen vision of leaders will play an important role in decision making by implementing ERP at its initial stages or supportive actions and follow up later after implementation stages. For this purpose, this research will highlight on the visionary sight of managers of having a daring decision to have an ERP system in their organization to enhance organizational performance as a result of practicing entrepreneurial activities.

\subsection{Entrepreneurial Orientation (EO)}

There has been published huge of research in the entrepreneurship field and entrepreneurial orientation, however, most of these researches are in the USA and few empirical studies focused on Europe (Frank, Kessler, \& Fink, 2010). There are many definitions for EO, for example, Zahra and Covin (1995) defined it as the potential instrument for refreshing organizations, where can be achieved through innovation, risk-taking, and proactiveness. In the literature, there is an agreement about the three dimensions of EO that they are positively related to performance (Covin \& Slevin, 1989; Miller, 1983; Zahra \& Covin, 1995). In addition, Frank et al. (2010) considered EO as the organizational strategic orientation of getting the certain entrepreneurial sides of methods, decision making, and practices.

The three previous dimensions mentioned of EO have been created by Miller (1983). Many studies after that followed Miller's model (Covin \& Slevin, 1989; Naman \& Slevin, 1993). Lumpkin and Dess (1996) have added other two dimensions, aggressiveness and autonomy.

Innovativeness was first pointed out by Schumpeter (1942) as an important dimension in the entrepreneurial process. It is related to creative processes, development of new ideas, and novelty (Lumpkin \& Dess, 1996). In addition, innovativeness grows profitability that gain from the first mover advantages (Wiklund, 1999). Sharma and Dave (2011) argued that innovativeness is considered as the major among other entrepreneurial profit traits. Moreover, innovativeness can increase the profit and growth of entrepreneurial organizations (Covin \& Wales, 2010). 
Proactiveness indicates to the willingness of organizations to anticipate in the recent development earlier to be the first mover to have an advantage against competitors, rather than wait and react to them (Frank et al., 2010). It is a forward looking to have opportunities for new services and products and respond to customers' demand (Lumpkin \& Dess, 2001). Therefore, the proactive organization will be a leader rather than a follower (Sharma \& Dave, 2011). Risk raking is the degree that managers have opportunities that seemed to have a chance of costly failure (Miller \& Friesen, 1978). So, it is the uncertainty of the result of behaving entrepreneurially (Kraus et al., 2012).

\subsection{Enterprise Resource Planning (ERP)}

Organizations around the world use the most modern and advanced technological systems and techniques to improve their performance, increase productivity, satisfy customers, and enhance business processes. The global competition in the market enforces organizations to have and implement systems that can make them in the line of business and achieve competitive advantages (Wei, 2007). ERP systems are one of these advanced and developed technologies that earned a significant growth in the last few years (Reilly, 2005).

An ERP system is a standard software package that involves different modules for particular functions such as inventory, finance, purchasing, human resources, fixed assets and others (Moller, 2005). The integration between these modules is the main issue of system complexity.

Leadership and its role in implementing ERP system has been studied by Walker (2004). He stated that the literature revealed that ERP project leaders focus on improving adaptive leadership strategies that integrated with innovative progress. Moreover, Forst (2004) assumed that ERP leadership is the most effective direction to achieve organizational objectives after implementation and have a competitive edge. In the last few years, organizations implemented ERP systems from different vendors such as Oracle, SAP, PeopleSoft and E.D Edwards to enhance and increase organizational performance by improving external and internal processes (Summer, 2005).

In connection to that, Davenport (2002) pointed out that in spite of the growth of ERP's sales by $10 \$$ billion every year, still there is a big gap between what has been accomplished and what was undertaken by vendors in terms of system efficiency and service delivery of the software. Therefore, if ERP system not implemented successfully and achieve what was proposed, may lead to organizational bankruptcy due to the uniqueness and integration features that report implementation failure (Davenport, 1998).

From the above few lines about ERP systems, we can come out with definitions of what ERP means; however, there is no agreement among researchers of one definition about ERP systems. Therefore, ERP is usually defined according to its role and approach that can play in an organization. One of the most significant definitions has been defined by Scalle and Cotteleer (1994) as an information system that integrates all business processes and operations such as sales, customer services, distribution, purchasing, manufacturing, production planning, and finance. Similarly, Davenport (2002) defined ERP as an advanced technological innovation and solution system that have the capability to integrate critical information inside an organization such as finance and accounting, customer relationship, supply chain, and human resource.

In relation to ERP benefits, Mabert, Soni, and Venkartaramanan (2003) identified many tangible benefits that can be gained from implementing ERP system such as improve order cycle, decrease financial close cycle, reduce direct operating costs, improve on-time delivery, lower inventory level, and improve interaction with customers. Most integration and implementation of ERP system in both private and public sectors gain many benefits and enhance competitive advantages, improve technology investment, and reduce costs (Mische, 2002). When comparing ERP systems with other systems, legacy systems are weak and limited in terms of technological changes, transforming components to another framework, and flexibility, in contrast with ERP systems that can overcome these limitations (Gupta \& Bhatia, 2005). In the line of this view, Roberto (2007) argued that ERP systems can improve integration between applications, expand the application of open source, improve security management, adopts software as a service, and adopts architecture of service-oriented.

The successfulness of ERP systems in any organization depends on different critical success factors (CSFs) that have been investigated by many writers (Huang et al., 2004; Murray \& Coffin, 2001). These factors can affect the performance of ERP and in turn on the whole performance of the organization. Therefore, it is very important for any organization to identify them and search for most successful resolutions. For example, Yang, Ting, and Wei (2006) identified six factors to measure ERP performance in term of system users' perspective, they are: information quality, users' satisfaction, system efficiency, system functions, use attitude, and system quality. In addition to that, Shad, Chen, and Azeem (2011) identified five critical factors that can lead the organization towards failure or success, they are: business process re-engineering, effective usage of process database, 
technical selection of quality consultant, architecture choices, and education on new business processes. In line with that, Somers and Nelson (2004) mentioned some critical factors such as selection of appropriate package, business process reengineering (BPR), clear goals and objectives, management of expectations, data analysis and conversion, change management, interdepartmental cooperation, user education and training, customization, dedicating resources, interdepartmental communication, project management, defining the architecture, and education on new processes.

\subsection{Entrepreneurial Orientation (EO) and Organizational Performance (OP)}

There is a bulk of research in literature taking about the relationship between EO and organizational performance. Some of the research found that EO has positive effect and significant on organizational performance (Lee, Lim, \& Pathak, 2011; Lumpkin \& Dess, 1996; Wang, 2008; Wiklund \& Shepherd, 2003), however on the other hand, some of them did not find a positive relationship between EO and organizational performance (Li, Zhang, \& Chan, 2005; Smart \& Conant, 1994), or negative impact on performance (Hart, 1992). The inclusiveness in results about the EO-organizational performance relationship, lead us to examine this relationship. Therefore, the following hypothesis is proposed to test this relationship:

\section{$\mathrm{H}_{1}$ : Entrepreneurial Orientation has a positive significant effect on the organizational performance.}

\subsection{Entrepreneurial Orientation (EO) and Enterprise Resource Planning (ERP)}

It has been argued that implementation process of ERP system is complex, challenging, and require high cost (Brown et al., 2009). In addition, Davenport (1998) argued that ERP systems are not like other traditional systems in terms of uniqueness and integration features that report a lot of implementation failures which may cause a bankruptcy to the whole organization. Therefore, implementation of ERP system is not an essay decision that can be taken by managers. They have to be aware of the risk that can affect the performance of the organization if unsuccessful implementation of ERP system. Unless managers have entrepreneurial vision, they can take a step of doing that

Entrepreneurial orientation of organizations' managers are the only way to implementation some risky and complex practices such as ERP system. EO has three important elements, risk-taking, proactiveness, and innovativeness. All these three dimensions are influencing managers to have an entrepreneurial personality to take unpredicted and rare decisions. For the complexity and problems when Implementation of ERP that have been mentioned before, EO dimensions may help in leading organizations to implement ERP and take the advantages and benefits over competitors. Therefore, we suppose that EO personality features of managers can lead organizations to implement ERP system and ultimately achieve high organizational performance. Thus the following hypothesis is proposed:

\section{$\mathbf{H}_{2}$ : Entrepreneurial Orientation has a positive significant effect on the Enterprise Resource Planning}

\subsection{Enterprise Resource Planning (ERP) and Organizational Performance}

Literature of ERP has a plenty of research work that has been conducted to examine the relationship between ERP and organizational performance. The reason behind these researches is the importance of the ERP system to improve organizational efficiency and effectiveness (non-financial performance) and at the end the financial performance (Kallunki, Laitinen, \& Silvola, 2011). Previous studies reported that ERP affected performance positively; however other results showed contradict results (Kang, Park, \& Yang, 2008). Bendoly and Kaefer (2004) argued that ERP systems improved performance, while others such as Evan and Bragg (1997), and Laughlin (1999) found that ERP systems raise performance in specific areas. In addition, other studies reported a negative impact of ERP systems on organizational performance because of several critical factors such as education, training top management and commitment, culture, and others.

For example, Poston and Grabski (2001) studied the effect of ERP system on organizational performance during 3 years. Their results showed that there is a decrease in cost of goods sold and a reduction in the ration of employees to revenue, whereas there is no significant difference in the ratio of residual income, expenses, and selling. In another study, Madapusi and D'Souza (2012) investigated the relationship between implementation of ERP and operational performance. They suggested more comprehension of the ERP-performance relationship that can be earned if researchers and managers test changes in the system and modular levels. In relation to that, Park, Suh, and Yang (2007) in their study investigated the effect of ERP systems on organizational performance in a Korean context by using data collected from 245 respondents in 20 Korean companies that have ERP systems. Their results stated that the users' knowledge and capacity play a direct and indirect effect on its value and finally impact positively on organizational performance.

In the same vein of research, Kallunki, Laitinen, and Silvola (2011) examined in their empirical study the role of 
management control system as a mediator between ERP system and organizational performance based on data collected from 70 Finnish firms. They found that the informal management control plays a positive role between ERP and non-financial organizational performance.

On the opposite side, some other studies did not find a positive relationship between implementation of ERP systems and organizational performance. For example, Hunton, Lippincott, and Reck (2003) investigated the ERP-performance relationship by comparing return on assets, asset turnover, and return on investment of adopters and non-adopters of ERP. They found that there is existed improvement in performance of ERP adopters. In addition, Wieder, Booth, Matolcsy, and Ossimitz, (2006) examined the impact of ERP system on business process performance among Australian companies. Their results showed that there is no significant difference between ERP adopters and non-adopters.

The conflicting past results of the relationship between ERP systems on organizational performance call for more researches to investigate and search more of the factors that can increase performance while implementing ERP systems. Therefore, the following hypothesis is proposed:

\section{$\mathbf{H}_{3}$ : Enterprise Resource Planning has a positive significant effect on the organizational performance.}

\subsection{The Mediating Role of ERP between EO and Organizational Performance}

It has been argued by Kumar et al. (2002) that ERP system is a complex system because of it integrates different modules and processes to automate the material, flow of information, and financial resources in the organization by using one database. In addition to that, Motwani, Mirchandani, Madan, \& Gunasekaran (2002) ERP brings changes in business processes and IT changes to improve flexibility, quality, cost, responsive, and performance. We can notice that ERP implementation is difficult either before implementation due to unusual decision making than can be made by managers to invest in a costly system or during the implementation stage where users and managers face difficulties to change the traditional processes they used to use. For these reasons, implementation in ERP system is not an easy task that can be decided by managers unless they have entrepreneurial orientation and expectation. Managers' traits such as risk-taking, innovativeness, and proactiveness can be fulfilled and translated to achieve high performance by implementing system like ERP. ERP system can help managers to accomplish their entrepreneurial goals and objectives to have the advantages of proactiveness and innovation in the market. Therefore, ERP is proposed here to mediate the relationship between EO and organizational performance by the following hypothesis:

\section{$\mathrm{H}_{4}$ : Enterprise Resource Planning (ERP) mediates the relationship between Entrepreneurial Orientation} (EO) and Organizational Performance.

\section{Methodology}

To examine the hypothesized model of this study, the data were collected from head section officers in Dubai Police. The Survey questionnaire was used as a medium of collecting data. It consisted of 64 questions. The operational definition of the ERP has been adopted from Stratman and Roth (2002) using a 7-point Likert scales. The questions of organizational performance were based on Balanced Scored Card that developed by Kaplan and Norton (1992) with 5-point Liker Scales. The questions of entrepreneurial orientation have been adopted from Covin and Slevin (1989) with 5-point Likert Scales.

Hundred and fifty questionnaires were distributed, out of which only one hundred and eleven questionnaires constituting a $74 \%$ response rate were returned. SPSS and PLS statistical programs were used to analyze the data collected.

\section{Statistical Analysis and Results}

To confirm the validity and reliability of the outer model, the Partial Least Squares (PLS) approach using Smart PLS 2.0 was employed. Validity and reliability are preliminary tests before examining the models and hypotheses.

This study tried to examine the model involving entrepreneurial orientation, ERP, and organizational performance, therefore, a two-step approach proposed by Chin (1998) was followed. 


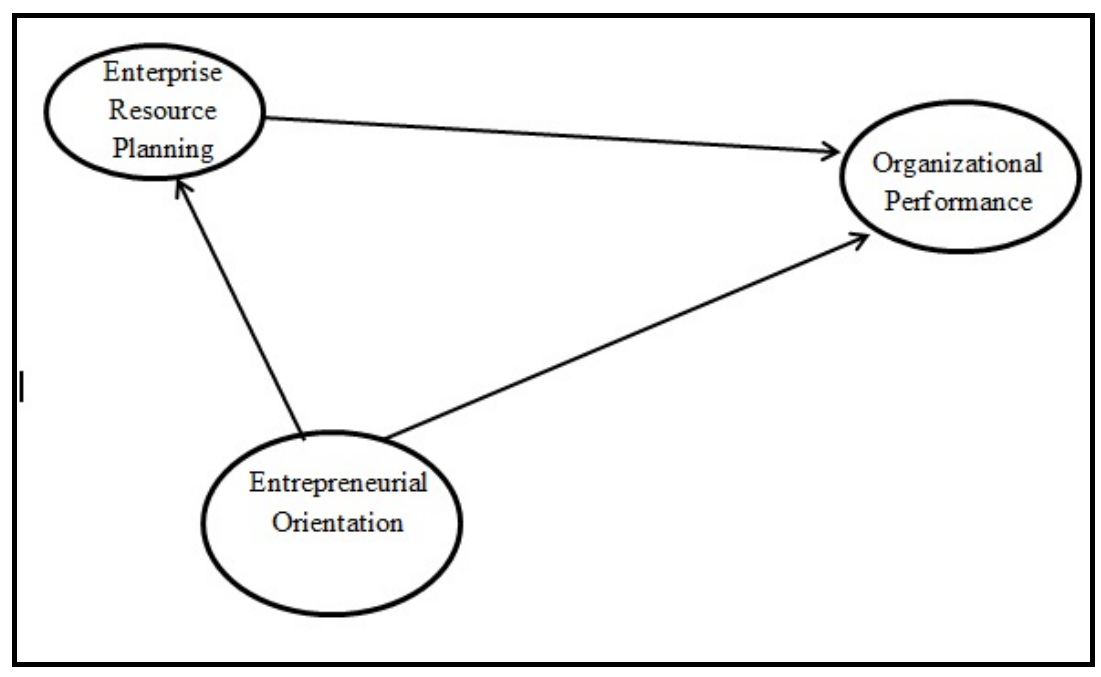

Figure 1. The research framework

As a usual practice in the literature of the structural equation modeling, the construct reliability and validity were proved before testing the hypothesized relationships.

\subsection{The Measurement, Outer, Model}

As discussed in the following sections, the construct validity and reliability were confirmed before establishing the goodness of measurement model. The construct validity and reliability were examined through the content validity, the convergent validity, and the discriminant validity as detailed in the following.

\subsubsection{The Content Validity}

In the literature of multivariate analysis, the constructs content validity is defined as the case when all the items used to measure a construct display high loadings on that construct compared with other constructs in the model. Accordingly, Hair et al. (2010) and Chin (1998) suggested that the factor loading has to be used to examine the content validity. Therefore, items will be deleted if they're loaded on other constructs higher than their loadings on their respective ones. As depicted in Table 1 and Table 2, all the variables are significantly loaded on their respective constructs. This result confirmed that the measurement model in this study has the required content validity.

Table 1. Factor analysis results

\begin{tabular}{|c|c|c|c|c|c|c|c|c|c|c|c|c|c|c|c|}
\hline Items & INN & PRO & RT & PB & PC & $\mathbf{P E}$ & PI & PL & $\mathbf{P P}$ & PS & PT & $\mathbf{F}$ & $\mathrm{C}$ & LG & IP \\
\hline EOI1 & 0.902 & 0.342 & 0.471 & 0.521 & 0.591 & 0.412 & 0.541 & 0.556 & 0.476 & 0.449 & 0.547 & 0.235 & 0.244 & 0.264 & 0.264 \\
\hline EOI2 & 0.869 & 0.356 & 0.248 & 0.311 & 0.442 & 0.333 & 0.392 & 0.409 & 0.423 & 0.324 & 0.384 & 0.369 & 0.263 & 0.266 & 0.341 \\
\hline EOI3 & 0.760 & 0.371 & 0.310 & 0.391 & 0.257 & 0.417 & 0.439 & 0.314 & 0.223 & 0.470 & 0.420 & 0.183 & 0.244 & 0.345 & 0.297 \\
\hline EOP2 & 0.439 & 0.890 & 0.482 & 0.182 & 0.204 & 0.424 & 0.178 & 0.172 & 0.447 & 0.312 & 0.256 & 0.361 & 0.466 & 0.503 & 0.444 \\
\hline EOP3 & 0.300 & 0.881 & 0.556 & 0.199 & 0.068 & 0.102 & 0.152 & 0.027 & 0.410 & 0.152 & 0.207 & 0.290 & 0.533 & 0.609 & 0.508 \\
\hline EOR1 & 0.236 & 0.669 & 0.816 & 0.242 & 0.172 & 0.285 & 0.182 & 0.117 & 0.423 & 0.317 & 0.265 & 0.253 & 0.471 & 0.522 & 0.382 \\
\hline EOR2 & 0.444 & 0.532 & 0.934 & 0.499 & 0.357 & 0.394 & 0.410 & 0.291 & 0.441 & 0.336 & 0.361 & 0.338 & 0.503 & 0.566 & 0.378 \\
\hline EOR3 & 0.384 & 0.302 & 0.834 & 0.590 & 0.464 & 0.372 & 0.470 & 0.462 & 0.425 & 0.368 & 0.407 & 0.277 & 0.414 & 0.334 & 0.138 \\
\hline ERPB1 & 0.380 & 0.036 & 0.229 & 0.849 & 0.698 & 0.480 & 0.851 & 0.770 & 0.484 & 0.590 & 0.778 & 0.048 & 0.177 & 0.385 & 0.243 \\
\hline ERPB2 & 0.479 & 0.235 & 0.487 & 0.854 & 0.632 & 0.647 & 0.852 & 0.768 & 0.538 & 0.656 & 0.710 & 0.167 & 0.320 & 0.411 & 0.349 \\
\hline ERPB3 & 0.485 & 0.246 & 0.608 & 0.874 & 0.608 & 0.505 & 0.721 & 0.649 & 0.498 & 0.505 & 0.655 & 0.246 & 0.477 & 0.379 & 0.387 \\
\hline ERPB4 & 0.365 & 0.202 & 0.500 & 0.907 & 0.651 & 0.502 & 0.700 & 0.697 & 0.587 & 0.620 & 0.664 & 0.239 & 0.366 & 0.457 & 0.305 \\
\hline ERPB5 & 0.377 & 0.211 & 0.367 & 0.781 & 0.616 & 0.522 & 0.572 & 0.545 & 0.439 & 0.517 & 0.649 & 0.193 & 0.218 & 0.336 & 0.275 \\
\hline ERPC1 & 0.488 & 0.199 & 0.381 & 0.710 & 0.852 & 0.564 & 0.746 & 0.788 & 0.653 & 0.470 & 0.686 & 0.456 & 0.359 & 0.314 & 0.434 \\
\hline
\end{tabular}




\begin{tabular}{|c|c|c|c|c|c|c|c|c|c|c|c|c|c|c|c|}
\hline Items & INN & PRO & RT & PB & PC & PE & PI & PL & PP & PS & PT & $\mathbf{F}$ & $\mathrm{C}$ & LG & IP \\
\hline ERPC2 & 0.436 & 0.177 & 0.361 & 0.671 & 0.919 & 0.320 & 0.640 & 0.717 & 0.609 & 0.343 & 0.682 & 0.374 & 0.277 & 0.354 & 0.211 \\
\hline ERPC3 & 0.402 & 0.087 & 0.354 & 0.599 & 0.874 & 0.427 & 0.629 & 0.725 & 0.544 & 0.418 & 0.704 & 0.190 & 0.098 & 0.270 & 0.101 \\
\hline ERPC4 & 0.454 & 0.060 & 0.292 & 0.688 & 0.940 & 0.463 & 0.679 & 0.763 & 0.590 & 0.378 & 0.735 & 0.308 & 0.184 & 0.295 & 0.244 \\
\hline ERPC5 & 0.528 & 0.163 & 0.306 & 0.672 & 0.871 & 0.585 & 0.631 & 0.768 & 0.615 & 0.490 & 0.719 & 0.361 & 0.228 & 0.305 & 0.244 \\
\hline ERPE1 & 0.310 & 0.055 & 0.228 & 0.594 & 0.594 & 0.887 & 0.620 & 0.515 & 0.462 & 0.710 & 0.635 & 0.217 & 0.156 & 0.327 & 0.322 \\
\hline ERPE2 & 0.469 & 0.297 & 0.391 & 0.622 & 0.493 & 0.933 & 0.555 & 0.529 & 0.433 & 0.775 & 0.631 & 0.207 & 0.284 & 0.348 & 0.324 \\
\hline ERPE3 & 0.470 & 0.465 & 0.539 & 0.564 & 0.420 & 0.911 & 0.471 & 0.490 & 0.524 & 0.807 & 0.531 & 0.241 & 0.398 & 0.414 & 0.370 \\
\hline ERPE4 & 0.445 & 0.305 & 0.346 & 0.507 & 0.447 & 0.951 & 0.488 & 0.440 & 0.455 & 0.713 & 0.555 & 0.303 & 0.349 & 0.389 & 0.428 \\
\hline ERPI1 & 0.516 & 0.091 & 0.381 & 0.731 & 0.767 & 0.574 & 0.835 & 0.722 & 0.616 & 0.616 & 0.649 & 0.362 & 0.258 & 0.283 & 0.407 \\
\hline ERPI2 & 0.354 & 0.068 & 0.192 & 0.677 & 0.542 & 0.342 & 0.876 & 0.635 & 0.411 & 0.518 & 0.611 & -0.002 & 0.226 & 0.317 & 0.362 \\
\hline ERPI3 & 0.466 & 0.213 & 0.374 & 0.715 & 0.579 & 0.530 & 0.883 & 0.644 & 0.450 & 0.549 & 0.693 & 0.125 & 0.318 & 0.333 & 0.476 \\
\hline ERPI4 & 0.599 & 0.247 & 0.477 & 0.872 & 0.736 & 0.637 & 0.933 & 0.793 & 0.492 & 0.616 & 0.845 & 0.224 & 0.392 & 0.450 & 0.445 \\
\hline ERPI5 & 0.395 & 0.174 & 0.312 & 0.764 & 0.585 & 0.399 & 0.802 & 0.717 & 0.486 & 0.541 & 0.669 & 0.124 & 0.222 & 0.485 & 0.274 \\
\hline ERPL1 & 0.362 & 0.126 & 0.274 & 0.673 & 0.590 & 0.356 & 0.698 & 0.760 & 0.438 & 0.511 & 0.712 & 0.038 & 0.137 & 0.344 & 0.191 \\
\hline ERPL2 & 0.289 & 0.125 & 0.277 & 0.754 & 0.564 & 0.566 & 0.712 & 0.779 & 0.405 & 0.580 & 0.663 & 0.114 & 0.265 & 0.263 & 0.456 \\
\hline ERPL3 & 0.418 & 0.024 & 0.325 & 0.690 & 0.844 & 0.502 & 0.638 & 0.861 & 0.540 & 0.524 & 0.683 & 0.295 & 0.136 & 0.227 & 0.201 \\
\hline ERPL4 & 0.508 & 0.089 & 0.286 & 0.610 & 0.756 & 0.360 & 0.666 & 0.880 & 0.557 & 0.451 & 0.628 & 0.121 & 0.085 & 0.183 & 0.135 \\
\hline ERPL5 & 0.537 & 0.110 & 0.184 & 0.581 & 0.701 & 0.409 & 0.627 & 0.817 & 0.447 & 0.399 & 0.551 & 0.213 & 0.094 & 0.053 & 0.208 \\
\hline ERPP1 & 0.289 & 0.376 & 0.360 & 0.512 & 0.540 & 0.341 & 0.531 & 0.456 & 0.870 & 0.334 & 0.359 & 0.392 & 0.415 & 0.515 & 0.526 \\
\hline ERPP2 & 0.317 & 0.499 & 0.365 & 0.496 & 0.569 & 0.399 & 0.520 & 0.486 & 0.893 & 0.420 & 0.424 & 0.341 & 0.399 & 0.512 & 0.515 \\
\hline ERPP3 & 0.418 & 0.352 & 0.510 & 0.582 & 0.667 & 0.549 & 0.545 & 0.654 & 0.882 & 0.526 & 0.456 & 0.435 & 0.420 & 0.443 & 0.414 \\
\hline ERPP4 & 0.458 & 0.501 & 0.532 & 0.515 & 0.574 & 0.464 & 0.463 & 0.479 & 0.876 & 0.468 & 0.397 & 0.472 & 0.436 & 0.447 & 0.399 \\
\hline ERPP5 & 0.430 & 0.331 & 0.317 & 0.418 & 0.508 & 0.384 & 0.341 & 0.364 & 0.716 & 0.404 & 0.409 & 0.436 & 0.318 & 0.420 & 0.326 \\
\hline ERPS1 & 0.500 & 0.310 & 0.495 & 0.624 & 0.488 & 0.706 & 0.607 & 0.580 & 0.483 & 0.840 & 0.561 & 0.073 & 0.253 & 0.340 & 0.230 \\
\hline ERPS2 & 0.557 & 0.321 & 0.489 & 0.643 & 0.411 & 0.695 & 0.622 & 0.569 & 0.491 & 0.894 & 0.553 & 0.097 & 0.267 & 0.370 & 0.298 \\
\hline ERPS3 & 0.388 & 0.167 & 0.228 & 0.480 & 0.254 & 0.627 & 0.475 & 0.402 & 0.344 & 0.882 & 0.400 & 0.055 & 0.013 & 0.241 & 0.193 \\
\hline ERPS4 & 0.310 & 0.210 & 0.278 & 0.672 & 0.471 & 0.738 & 0.598 & 0.553 & 0.517 & 0.889 & 0.595 & 0.070 & 0.121 & 0.338 & 0.287 \\
\hline ERPS5 & 0.378 & 0.121 & 0.188 & 0.513 & 0.403 & 0.781 & 0.545 & 0.498 & 0.364 & 0.856 & 0.608 & 0.011 & -0.013 & 0.266 & 0.255 \\
\hline ERPT1 & 0.356 & 0.109 & 0.206 & 0.695 & 0.706 & 0.503 & 0.746 & 0.633 & 0.383 & 0.439 & 0.822 & 0.192 & 0.198 & 0.374 & 0.378 \\
\hline ERPT2 & 0.448 & 0.186 & 0.374 & 0.572 & 0.593 & 0.445 & 0.505 & 0.557 & 0.345 & 0.423 & 0.734 & 0.061 & 0.185 & 0.430 & 0.130 \\
\hline ERPT3 & 0.505 & 0.264 & 0.413 & 0.607 & 0.631 & 0.568 & 0.583 & 0.608 & 0.384 & 0.542 & 0.845 & 0.075 & 0.281 & 0.403 & 0.277 \\
\hline ERPT4 & 0.380 & 0.235 & 0.255 & 0.718 & 0.689 & 0.481 & 0.685 & 0.705 & 0.398 & 0.527 & 0.839 & 0.200 & 0.243 & 0.346 & 0.335 \\
\hline ERPT5 & 0.507 & 0.268 & 0.381 & 0.699 & 0.602 & 0.604 & 0.736 & 0.706 & 0.444 & 0.618 & 0.827 & 0.076 & 0.188 & 0.351 & 0.365 \\
\hline OP1 & 0.220 & 0.344 & 0.188 & 0.078 & 0.232 & 0.185 & 0.102 & 0.057 & 0.373 & 0.037 & 0.084 & 0.906 & 0.573 & 0.542 & 0.499 \\
\hline OP4 & 0.325 & 0.272 & 0.438 & 0.322 & 0.465 & 0.280 & 0.276 & 0.324 & 0.481 & 0.096 & 0.195 & 0.776 & 0.571 & 0.335 & 0.417 \\
\hline OP5 & 0.107 & 0.424 & 0.415 & 0.257 & 0.224 & 0.082 & 0.213 & 0.103 & 0.454 & -0.072 & 0.059 & 0.525 & 0.779 & 0.456 & 0.548 \\
\hline OP6 & 0.308 & 0.577 & 0.553 & 0.374 & 0.334 & 0.343 & 0.351 & 0.222 & 0.493 & 0.288 & 0.367 & 0.588 & 0.789 & 0.576 & 0.558 \\
\hline OP7 & 0.135 & 0.354 & 0.232 & 0.128 & 0.049 & 0.154 & 0.146 & -0.023 & 0.214 & 0.061 & 0.094 & 0.371 & 0.678 & 0.676 & 0.522 \\
\hline OP8 & 0.118 & 0.431 & 0.420 & 0.266 & 0.128 & 0.142 & 0.256 & 0.047 & 0.312 & 0.186 & 0.190 & 0.349 & 0.590 & 0.789 & 0.472 \\
\hline OP9 & 0.194 & 0.541 & 0.446 & 0.148 & 0.107 & 0.275 & 0.170 & -0.006 & 0.347 & 0.146 & 0.295 & 0.360 & 0.556 & 0.791 & 0.462 \\
\hline OP10 & 0.211 & 0.428 & 0.262 & 0.441 & 0.320 & 0.426 & 0.410 & 0.305 & 0.440 & 0.363 & 0.406 & 0.367 & 0.410 & 0.745 & 0.539 \\
\hline OP11 & 0.492 & 0.499 & 0.540 & 0.539 & 0.479 & 0.376 & 0.469 & 0.442 & 0.555 & 0.397 & 0.509 & 0.541 & 0.622 & 0.711 & 0.512 \\
\hline OP12 & 0.151 & 0.427 & 0.180 & 0.170 & 0.196 & 0.159 & 0.231 & 0.084 & 0.466 & 0.048 & 0.212 & 0.475 & 0.689 & 0.514 & 0.836 \\
\hline OP13 & 0.318 & 0.374 & 0.368 & 0.483 & 0.322 & 0.437 & 0.604 & 0.445 & 0.393 & 0.410 & 0.456 & 0.199 & 0.498 & 0.464 & 0.813 \\
\hline OP14 & 0.412 & 0.531 & 0.353 & 0.300 & 0.209 & 0.401 & 0.358 & 0.243 & 0.428 & 0.305 & 0.298 & 0.640 & 0.634 & 0.646 & 0.865 \\
\hline OP15 & 0.412 & 0.500 & 0.350 & 0.300 & 0.209 & 0.415 & 0.358 & 0.243 & 0.428 & 0.305 & 0.298 & 0.638 & 0.635 & 0.647 & 0.865 \\
\hline
\end{tabular}


Table 2. Factor loadings significance

\begin{tabular}{|c|c|c|c|c|c|}
\hline Construct & Items & Loadings & StdError & T Value & P Value \\
\hline \multirow[t]{3}{*}{ EO-Innovativeness } & EOI1 & 0.902 & 0.015 & 61.875 & 0.000 \\
\hline & EOI2 & 0.869 & 0.026 & 33.349 & 0.000 \\
\hline & EOI3 & 0.760 & 0.054 & 14.039 & 0.000 \\
\hline \multirow[t]{2}{*}{ EO-Proactiveness } & EOP2 & 0.890 & 0.026 & 34.245 & 0.000 \\
\hline & EOP3 & 0.881 & 0.021 & 42.489 & 0.000 \\
\hline \multirow[t]{3}{*}{ EO-Risk Taking } & EOR1 & 0.816 & 0.055 & 14.806 & 0.000 \\
\hline & EOR2 & 0.934 & 0.012 & 76.886 & 0.000 \\
\hline & EOR3 & 0.834 & 0.048 & 17.246 & 0.000 \\
\hline \multirow[t]{5}{*}{ ERP-Business Process Skills } & ERPB1 & 0.849 & 0.033 & 25.761 & 0.000 \\
\hline & ERPB2 & 0.854 & 0.027 & 32.231 & 0.000 \\
\hline & ERPB3 & 0.874 & 0.026 & 33.288 & 0.000 \\
\hline & ERPB4 & 0.907 & 0.023 & 39.980 & 0.000 \\
\hline & ERPB5 & 0.781 & 0.056 & 13.903 & 0.000 \\
\hline \multirow[t]{5}{*}{ ERP-Change Readiness } & ERPC1 & 0.852 & 0.037 & 23.334 & 0.000 \\
\hline & ERPC2 & 0.919 & 0.028 & 32.576 & 0.000 \\
\hline & ERPC3 & 0.874 & 0.019 & 45.501 & 0.000 \\
\hline & ERPC4 & 0.940 & 0.012 & 76.173 & 0.000 \\
\hline & ERPC5 & 0.871 & 0.026 & 33.103 & 0.000 \\
\hline \multirow[t]{4}{*}{ ERP-Executive Commitment } & ERPE1 & 0.887 & 0.033 & 27.153 & 0.000 \\
\hline & ERPE2 & 0.933 & 0.020 & 46.476 & 0.000 \\
\hline & ERPE3 & 0.911 & 0.023 & 40.249 & 0.000 \\
\hline & ERPE4 & 0.951 & 0.013 & 73.927 & 0.000 \\
\hline \multirow[t]{5}{*}{ ERP-IT Skills } & ERPI1 & 0.835 & 0.039 & 21.670 & 0.000 \\
\hline & ERPI2 & 0.876 & 0.028 & 31.431 & 0.000 \\
\hline & ERPI3 & 0.883 & 0.027 & 32.339 & 0.000 \\
\hline & ERPI4 & 0.933 & 0.014 & 68.171 & 0.000 \\
\hline & ERPI5 & 0.802 & 0.061 & 13.079 & 0.000 \\
\hline \multirow[t]{5}{*}{ ERP-Learning } & ERPL1 & 0.760 & 0.048 & 15.910 & 0.000 \\
\hline & ERPL2 & 0.779 & 0.056 & 13.870 & 0.000 \\
\hline & ERPL3 & 0.861 & 0.023 & 37.410 & 0.000 \\
\hline & ERPL4 & 0.880 & 0.023 & 37.725 & 0.000 \\
\hline & ERPL5 & 0.817 & 0.048 & 17.095 & 0.000 \\
\hline \multirow[t]{5}{*}{ ERP-Project Management } & ERPP1 & 0.870 & 0.029 & 30.344 & 0.000 \\
\hline & ERPP2 & 0.893 & 0.023 & 39.378 & 0.000 \\
\hline & ERPP3 & 0.882 & 0.024 & 36.661 & 0.000 \\
\hline & ERPP4 & 0.876 & 0.027 & 31.869 & 0.000 \\
\hline & ERPP5 & 0.716 & 0.072 & 9.982 & 0.000 \\
\hline \multirow[t]{5}{*}{ ERP-Strategic IT Planning } & ERPS1 & 0.840 & 0.025 & 33.076 & 0.000 \\
\hline & ERPS2 & 0.894 & 0.015 & 58.968 & 0.000 \\
\hline & ERPS3 & 0.882 & 0.027 & 32.561 & 0.000 \\
\hline & ERPS4 & 0.889 & 0.027 & 33.360 & 0.000 \\
\hline & ERPS5 & 0.856 & 0.037 & 23.064 & 0.000 \\
\hline \multirow[t]{5}{*}{ ERP-Training } & ERPT1 & 0.822 & 0.033 & 24.635 & 0.000 \\
\hline & ERPT2 & 0.734 & 0.059 & 12.397 & 0.000 \\
\hline & ERPT3 & 0.845 & 0.026 & 31.969 & 0.000 \\
\hline & ERPT4 & 0.839 & 0.033 & 25.182 & 0.000 \\
\hline & ERPT5 & 0.827 & 0.035 & 23.501 & 0.000 \\
\hline
\end{tabular}




\begin{tabular}{llllll}
\hline Construct & Items & Loadings & StdError & T Value & P Value \\
\hline Financial & OP1 & $\mathbf{0 . 9 0 6}$ & 0.050 & 17.964 & 0.000 \\
Customer & OP4 & $\mathbf{0 . 7 7 6}$ & 0.088 & 8.774 & 0.000 \\
& OP5 & $\mathbf{0 . 7 7 9}$ & 0.038 & 20.341 & 0.000 \\
& OP6 & $\mathbf{0 . 7 8 9}$ & 0.065 & 11.903 & 0.000 \\
OP7 & $\mathbf{0 . 6 7 8}$ & 0.037 & 21.440 & 0.000 \\
Learning and Growth & OP8 & $\mathbf{0 . 5 9 0}$ & 0.062 & 10.989 & 0.000 \\
& OP9 & $\mathbf{0 . 7 9 1}$ & 0.042 & 18.947 & 0.000 \\
Internal Process & OP10 & $\mathbf{0 . 7 4 5}$ & 0.040 & 19.580 & 0.000 \\
& OP11 & $\mathbf{0 . 7 1 1}$ & 0.061 & 12.163 & 0.000 \\
& OP12 & $\mathbf{0 . 8 3 6}$ & 0.050 & 14.332 & 0.000 \\
& OP13 & $\mathbf{0 . 8 1 3}$ & 0.030 & 27.517 & 0.000 \\
& OP14 & $\mathbf{0 . 8 6 5}$ & 0.040 & 20.217 & 0.000 \\
& OP15 & $\mathbf{0 . 8 6 5}$ & 0.025 & 34.093 & 0.000 \\
\hline
\end{tabular}

\subsubsection{The Convergent Validity}

The convergent validity is defined to be the degree to which a group of items converge to measure a particular construct (Hair et al., 2010). According to the literature of SEM, it can be proven by examining the loadings, the composite reliability, and the average variance extracted. In other words, the contructs' items that are highly loaded and significant statistically in measuring constructs with 0.7 at least of factor loading, the average variance extracted (AVE) is at least 0.5 for each construct, and the composite reliability is at least 0.831 for each construct more than the cutoff value (0.7). Therefore, the result showed that the measurement model, outer model, has an appropriate convergent validity (Bagozzi \& Yi, 1988).

Table 3 below show the results of the composite reliability values for all the construct. They are more than 0.7 (the recommended value), and the AVE values more than 0.5 . Thus, we can confirm the adequacy of the level of convergent validity of the measurement model.

Table 3. Convergent validity analysis

\begin{tabular}{|c|c|c|c|c|}
\hline Construct & Items & Loadings & Composite Reliability & Average Variance Extracted \\
\hline \multirow[t]{3}{*}{ EO-Innovativeness } & EOI1 & 0.902 & 0.883 & 0.716 \\
\hline & EOI2 & 0.869 & & \\
\hline & EOI3 & 0.760 & & \\
\hline \multirow[t]{2}{*}{ EO-Proactiveness } & EOP2 & 0.890 & 0.879 & 0.783 \\
\hline & EOP3 & 0.881 & & \\
\hline \multirow[t]{3}{*}{ EO-Risk Taking } & EOR1 & 0.816 & 0.897 & 0.745 \\
\hline & EOR2 & 0.934 & & \\
\hline & EOR3 & 0.834 & & \\
\hline \multirow[t]{5}{*}{ ERP-Business Process Skills } & ERPB1 & 0.849 & 0.931 & 0.730 \\
\hline & ERPB2 & 0.854 & & \\
\hline & ERPB3 & 0.874 & & \\
\hline & ERPB4 & 0.907 & & \\
\hline & ERPB5 & 0.781 & & \\
\hline \multirow[t]{5}{*}{ ERP-Change Readiness } & ERPC1 & 0.852 & 0.951 & 0.796 \\
\hline & ERPC2 & 0.919 & & \\
\hline & ERPC3 & 0.874 & & \\
\hline & ERPC4 & 0.940 & & \\
\hline & ERPC5 & 0.871 & & \\
\hline \multirow[t]{3}{*}{ ERP-Executive Commitment } & ERPE1 & 0.887 & 0.957 & 0.848 \\
\hline & ERPE2 & 0.933 & & \\
\hline & ERPE3 & 0.911 & & \\
\hline
\end{tabular}




\begin{tabular}{|c|c|c|c|c|}
\hline Construct & Items & Loadings & Composite Reliability & Average Variance Extracted \\
\hline & ERPE4 & 0.951 & & \\
\hline \multirow[t]{5}{*}{ ERP-IT Skills } & ERPI1 & 0.835 & 0.938 & 0.751 \\
\hline & ERPI2 & 0.876 & & \\
\hline & ERPI3 & 0.883 & & \\
\hline & ERPI4 & 0.933 & & \\
\hline & ERPI5 & 0.802 & & \\
\hline \multirow[t]{5}{*}{ ERP-Learning } & ERPL1 & 0.760 & 0.911 & 0.673 \\
\hline & ERPL2 & 0.779 & & \\
\hline & ERPL3 & 0.861 & & \\
\hline & ERPL4 & 0.880 & & \\
\hline & ERPL5 & 0.817 & & \\
\hline \multirow[t]{5}{*}{ ERP-Project Management } & ERPP1 & 0.870 & 0.928 & 0.722 \\
\hline & ERPP2 & 0.893 & & \\
\hline & ERPP3 & 0.882 & & \\
\hline & ERPP4 & 0.876 & & \\
\hline & ERPP5 & 0.716 & & \\
\hline \multirow[t]{5}{*}{ ERP-Strategic IT Planning } & ERPS1 & 0.840 & 0.941 & 0.761 \\
\hline & ERPS2 & 0.894 & & \\
\hline & ERPS3 & 0.882 & & \\
\hline & ERPS4 & 0.889 & & \\
\hline & ERPS5 & 0.856 & & \\
\hline \multirow[t]{5}{*}{ ERP-Training } & ERPT1 & 0.822 & 0.908 & 0.663 \\
\hline & ERPT2 & 0.734 & & \\
\hline & ERPT3 & 0.845 & & \\
\hline & ERPT4 & 0.839 & & \\
\hline & ERPT5 & 0.827 & & \\
\hline \multirow[t]{2}{*}{ Financial } & OP1 & 0.906 & 0.831 & 0.711 \\
\hline & OP4 & 0.776 & & \\
\hline \multirow[t]{4}{*}{ Customer } & OP5 & 0.779 & 0.841 & 0.571 \\
\hline & OP6 & 0.789 & & \\
\hline & OP7 & 0.678 & & \\
\hline & OP8 & 0.590 & & \\
\hline \multirow[t]{4}{*}{ Learning and Growth } & OP9 & 0.791 & 0.845 & 0.577 \\
\hline & OP10 & 0.745 & & \\
\hline & OP11 & 0.711 & & \\
\hline & OP12 & 0.836 & & \\
\hline \multirow[t]{3}{*}{ Internal Process } & OP13 & 0.813 & 0.876 & 0.703 \\
\hline & OP14 & 0.865 & & \\
\hline & OP15 & 0.865 & & \\
\hline
\end{tabular}

a: $\mathrm{CR}=(\Sigma \text { factor loading })^{2} /\left\{(\Sigma \text { factor loading })^{2}\right)+\Sigma$ (variance of error $\left.)\right\}$

b: AVE $=\Sigma(\text { factor loading })^{2} /(\Sigma \text { (factor loading })^{2}+\Sigma($ variance of error $\left.)\right\}$

\subsubsection{The Discriminant Validity}

In the SEM literature, the discriminant validity is defined as the degree to which a group of items can distinguish a construct from other constructs in the model. In other words, the items of each construct should have a variance among them greater than that shared with other constructs (Compeau et al., 1999). A criterion was suggested by Fornell and Larcker (1981) to test this type of validity. In Table 4 below, there is a diagonal line of elements that are the square roots of the AVE and below those diagonal elements are the correlations of the variables. A comparison can be made between the diagonal elements and the off diagonal ones. Therefore, the discriminant validity can be confirmed and assumed if the values of the diagonal elements are higher than other values in their 
respective rows and columns. Therefore, the discriminant validity has been confirmed according to the Fornell and Larcker's (1981) criterion.

Table 4. Correlations and discriminant validity

\begin{tabular}{|c|c|c|c|c|c|c|c|c|c|c|c|c|c|c|c|}
\hline Construct & 1 & 2 & 3 & 4 & 5 & 6 & 7 & 8 & 9 & 10 & 11 & 12 & 13 & 14 & 15 \\
\hline $\mathbf{C}$ & 0.756 & & & & & & & & & & & & & & \\
\hline $\mathbf{F}$ & 0.670 & 0.843 & & & & & & & & & & & & & \\
\hline INN & 0.295 & 0.308 & 0.846 & & & & & & & & & & & & \\
\hline IP & 0.731 & 0.546 & 0.352 & 0.838 & & & & & & & & & & & \\
\hline LG & 0.723 & 0.537 & 0.341 & 0.654 & 0.760 & & & & & & & & & & \\
\hline PB & 0.364 & 0.206 & 0.489 & 0.365 & 0.462 & 0.854 & & & & & & & & & \\
\hline PC & 0.260 & 0.382 & 0.520 & 0.281 & 0.345 & 0.751 & 0.892 & & & & & & & & \\
\hline PE & 0.319 & 0.262 & 0.459 & 0.390 & 0.401 & 0.623 & 0.534 & 0.921 & & & & & & & \\
\hline PI & 0.331 & 0.201 & 0.545 & 0.456 & 0.432 & 0.872 & 0.748 & 0.582 & 0.867 & & & & & & \\
\hline PL & 0.177 & 0.193 & 0.513 & 0.292 & 0.263 & 0.809 & 0.845 & 0.538 & 0.815 & 0.821 & & & & & \\
\hline PP & 0.470 & 0.488 & 0.450 & 0.513 & 0.549 & 0.598 & 0.677 & 0.509 & 0.570 & 0.584 & 0.850 & & & & \\
\hline PRO & 0.564 & 0.369 & 0.419 & 0.537 & 0.627 & 0.215 & 0.155 & 0.301 & 0.186 & 0.114 & 0.485 & 0.885 & & & \\
\hline PS & 0.155 & 0.072 & 0.491 & 0.293 & 0.361 & 0.680 & 0.473 & 0.817 & 0.659 & 0.603 & 0.511 & 0.264 & 0.873 & & \\
\hline PT & 0.269 & 0.151 & 0.538 & 0.372 & 0.464 & 0.811 & 0.792 & 0.641 & 0.806 & 0.791 & 0.482 & 0.262 & 0.629 & 0.814 & \\
\hline RT & 0.538 & 0.338 & 0.414 & 0.354 & 0.556 & 0.512 & 0.380 & 0.406 & 0.409 & 0.331 & 0.497 & 0.586 & 0.393 & 0.397 & 0.863 \\
\hline
\end{tabular}

\subsection{The Structural Model, Inner Model, and Hypothesis Testing}

When the construct reliability and construct validity have been examined and established, the next step was to test the proposed hypotheses of this study by running Algorithm and Bootstrapping in Smart PLS 2.0. Figure 2 and Table 6 below reported the results.

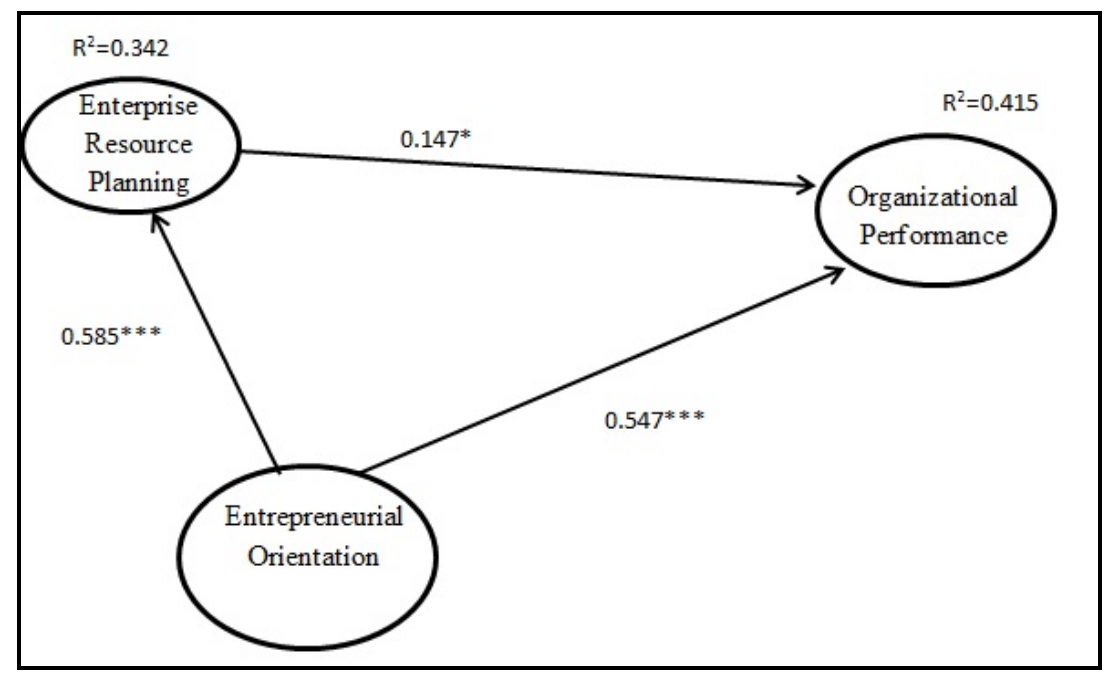

Figure 2. Hypothesis testing results 
Table 5. Hypothesis testing results

\begin{tabular}{|c|c|c|c|c|c|c|}
\hline Hy. No & Hypothesized Path & $\begin{array}{l}\text { Path } \\
\text { Coefficient }\end{array}$ & $\begin{array}{l}\text { Standard } \\
\text { Error }\end{array}$ & $\begin{array}{l}\mathrm{T} \\
\text { Value }\end{array}$ & $\begin{array}{l}\mathrm{P} \\
\text { Value }\end{array}$ & Decision \\
\hline $\mathrm{H}_{1}$ & $\begin{array}{l}\text { Entrepreneurial } \quad \text { Orientation } \\
\text { Enterprise Resource Planning }\end{array}$ & $0.585 * * *$ & 0.053 & 11.017 & 0.000 & Supported \\
\hline $\mathrm{H}_{2}$ & $\begin{array}{l}\text { Enterprise Resource Planning----> } \\
\text { Organizational Performance }\end{array}$ & $0.147^{*}$ & 0.074 & 1.999 & 0.046 & Supported \\
\hline $\mathrm{H}_{3}$ & $\begin{array}{l}\text { Entrepreneurial Orientation } \\
\text { Organizational Performance }\end{array}$ & $0.547 * * *$ & 0.060 & 9.167 & 0.000 & Supported \\
\hline \multicolumn{7}{|c|}{$* * *: \mathrm{p}<0.001 ; * *: \mathrm{p}<0.01 ; *: \mathrm{p}<0.05$} \\
\hline
\end{tabular}

As illustrated in Figure 2 and Table 5 EO has a positive and significant effect on the ERP at the 0.001 level of significance $(\beta=0.585, \mathrm{t}=11.017, \mathrm{p}<0.001)$. The results also show that ERP has a positive and significant effect on the organizational performance at the 0.05 level of significance $(\beta=0.147, \mathrm{t}=1.999, \mathrm{p}<0.05)$. Similarly, the EO also has a significant and positive effect on the organizational performance at the 0.001 level of significance $(\beta=0.547, \mathrm{t}=9.167, \mathrm{p}<0.001)$. Thus, the results supported the hypotheses of the study $\mathrm{H}_{1}, \mathrm{H}_{2}$, and $\mathrm{H}_{3}$ as developed in the study.

\subsubsection{Testing the Mediating Role of ERP}

To examine the mediating impact of the ERP between EO and OP, the PLS was applied to estimate the indirect effect among the variables. Table 6 below shows the results in which EO indirectly affects significantly the organizational performance at the 0.05 level of significance with indicators $(\beta=0.086, t=1.881, p<0.05)$. When the effect of the ERP was not taken into account, EO has a positive and significant effect on the organizational performance at the 0.001 level of significance $(\beta=0.640, \mathrm{t}=14.227, \mathrm{p}<0.001)$. Therefore, it can be concluded that ERP is a partial mediator between EO and organizational performance carrying out a $14 \%$, as a Variance Accounted for (VAF), of the influence of EO on OP. The mediating effect of the ERP has been supported according to the result of $\mathrm{H}_{4}$ that was hypothesized in the study.

Table 6. Mediation analysis results

\begin{tabular}{|c|c|c|c|c|c|c|c|c|}
\hline $\begin{array}{l}\text { Hyp. } \\
\text { No }\end{array}$ & Hypothesis & Path C & efficient & & $\begin{array}{l}\text { Standard } \\
\text { Error }\end{array}$ & $\begin{array}{l}\text { T } \\
\text { Value }\end{array}$ & $\begin{array}{l}\mathbf{P} \\
\text { Value }\end{array}$ & Decision \\
\hline & & $a * b$ & $\mathrm{C}$ & $\mathbf{c}^{\prime}$ & & & & \\
\hline $\mathrm{H}_{4}$ & $\begin{array}{l}\text { ERP mediates the effect } \\
\text { of EO on organizational } \\
\text { performance }\end{array}$ & $0.086^{*}$ & $0.640 * * *$ & $0.547 * * *$ & 0.046 & 1.881 & 0.030 & $\begin{array}{l}\text { Partial } \\
\text { Mediation }\end{array}$ \\
\hline
\end{tabular}

\subsection{Predictive Relevance of the Model}

$\mathrm{R}^{2}$ and Cross-Validated redundancy was utilized to examine the predictive power of the model. $\mathrm{R}^{2}$ refers to the variance in the endogenous variables that is being explained by the exogenous variables. In Table 7 below, the results showed $\mathrm{R}^{2}$ as $34.2 \%$ of the ERP that explained explained by the Entrepreneurial Orientation. In addition, $42 \%$ of the Organizational Performance was accounted for by the ERP and EO. Cohen (1988) suggested a value of $\mathrm{R}^{2}$ where 0.26 substantial, 0.13 moderate, and 0.02 weak. Therefore, both $\mathrm{R}^{2}$ values are considered substantial and the power of variables contained in the model in explaining the organizational performance.

In addition to $\mathrm{R}^{2}$, the Cross-Validated Redundancy values were used to assess the quality of the model. By running the Blindfolding procedures, these values can gain in Smart PLS that was applied to generate the cross-validated redundancy and cross-validated communality. The procedure of Blindfolding is based on removing some the values in the data and later on estimating them as missing values. After that, the estimated parameters are used to re-estimate the missing data. Then, a comparison will be used to examine how close the implied from the real results. If the data point estimation is achieved by the latent variables, the output is the cross-validated redundancy. 
Table 7. Prediction relevance of the model

\begin{tabular}{llll}
\hline Construct & R Square & $\begin{array}{l}\text { Cross } \\
\text { Redundancy }\end{array}$ & $\begin{array}{l}\text { Validated } \\
\text { Communality }\end{array}$ \\
\hline Entrepreneurial Orientation & & & 0.325 \\
Enterprise Resource Planning & 0.342 & 0.167 & 0.497 \\
Organizational Performance & 0.415 & 0.181 & 0.365 \\
\hline
\end{tabular}

According to Fornell and Cha (1994), the model under investigation will have the predictive quality if the cross-redundancy values were more than zero, else the predictive quality of the model cannot be confirmed. Table 7 showed the obtained cross validated redundancy of 0.17 for ERP and 0.18 for OP. therefore, these results confirmed that the model has adequate prediction quality.

\subsection{Goodness of Fit (GoF) of the Model}

PLS-SEM has only one measure of goodness of fit that was defined by Tenenhaus et al. (2005) to be the global fit. Therefore, it is the geometric mean of the AVE and the average $R^{2}$ for the endogenous variable in the following formula:

$$
G_{\mathrm{r}} \cap \mathrm{f}=\sqrt{\left(R^{2} \times \overline{\mathrm{AVF})}\right.}
$$

The baseline values of GoF suggested by Wetzels et al. (2009) is ( Accordingly, in this study the GoF value was 0.711 which is regarded to be large. Therefore, the result showed that the model GoF measure is large based on the average variance which refer an adequate level of PLS model validity.

Table 8. Goodness of fit

\begin{tabular}{llll}
\hline Construct & R Square & Average Variance Extracted & Goodness of Fit \\
\hline C & 0.854 & 0.571 & \\
F & 0.570 & 0.711 & \\
INN & 0.580 & 0.716 & \\
IP & 0.747 & 0.703 & \\
LG & 0.755 & 0.577 & \\
PB & 0.840 & 0.730 & \\
PC & 0.754 & 0.796 & \\
PE & 0.585 & 0.848 & \\
PI & 0.817 & 0.751 & \\
PL & 0.796 & 0.673 & \\
PP & 0.525 & 0.722 & \\
PRO & 0.628 & 0.783 & \\
PS & 0.620 & 0.761 & \\
PT & 0.784 & 0.663 & \\
RT & 0.732 & 0.745 & \\
Average & 0.706 & 0.717 & \\
\hline
\end{tabular}

\section{Discussion and Conclusion}

The main objective of this study was to examine the direct and indirect effect of EO on the organizational performance. For that, the mediating role of ERP system between EO and organizational performance was investigated. In other words, this study set out a task to examine the EO-ERP-organizational performance 
relationship. The results found the relationship of EO-Performance was mediated by ERP- a missing link in the prior literature. As an empirical study, the data have been collected from Dubai Police departments. The study employed the partial least squares structural equations modeling to examine the proposed model. The statistical results of the study showed that all the hypotheses were supported. In the first hypothesis, the impact of EO, however not linked in the previous literature, has a positive and significant effect on ERP at 0.001 level of significant $(\beta=0.585, \mathrm{t}=11.017, \mathrm{p}<0.001)$. In consistence with previous findings of Bendoly and Kaefer (2004), Park, Suh, and Yang (2007), and Poston and Grabski (2001); the second hypothesis supported that ERP has a positive and significant effect on organizational performance at the 0.05 level of significant $(\beta=0.147, t=1.999$, $\mathrm{p}<0.05$ ). In addition, the third hypothesis also support the argument that EO has a positive and significant effect on organizational performance at 0.001 level of significant $(\beta=0.547, t=9.167, p<0.001)$ in line with many studies found that firms with more EO perform better (Wiklund, 1999; Zahra, 1991; Zahra \& Covin, 1995). Therefore, it is clear that EO and ERP have positive and significant effect on organizational performance, respectively, however, the EO-ERP-performance relationship remain unsearched. Accordingly, the forth hypothesis, however, has been supported where EO was found to have indirect and significant effect on organizational performance $(\beta=0.086, \mathrm{t}=1.881, \mathrm{p}<0.05)$, and when in the effect of ERP intervened between them, the $\mathrm{EO}$ has a positive and significant effect on organizational performance $(\beta=0.640, \mathrm{t}=14.227, \mathrm{p}<0.001)$. Due to this result, we can conclude that ERP has a partial mediator effect between EO and organizational performance with $14 \%$ of VAF of the influence of $\mathrm{EO}$ on organizational performance.

The contribution of our study is in different theoretical aspects: first, the extension of other studies about the relationships between EO-OP and ERP-OP. Second, it is the first study to examine the effect of EO on ERP where has been supported. In other words, there is no study in the literature that examines statistically the effect of EO on ERP system. Therefore, this result will open a door for other researchers to investigate more and examine other factors that play a role in this relationship. Finally, it examined the role of ERP as a mechanism that explain the relationship between EO and organizational performance.

Practically, the results of our study have many practical implications. The results will help managers to take the proper decision when deciding to implement ERP system in their organizations. The ERP can help managers with strong EO to achieve the maximum performance in organizations. The competitive business environment make and the business more and more complex, and therefore, managers should have a competitive resource that can lead to accomplish the best results.

\section{References}

Al-Dhaafri, H. S., Bin Yusoff, R. Z., \& Al-Swidi, A. K. (2013). The Effect of Total Quality Management, Enterprise Resource Planning and the Entrepreneurial Orientation on the Organizational Performance: The Mediating Role of the Organizational Excellence-A Proposed Research Framework. International Journal of Business Administration, 4(1), 66-85. http://dx.doi.org/10.5430/ijba.v4n1p66

Bendoly, E., \& Kaefer, F. (2004). Business Technology Complementarities: Impacts of the Presence and Strategic Timing of ERP on B2B E-commerce Technology Efficiencies. Omega, 32(5), 395-406. http://dx.doi.org/10.1016/j.omega.2004.02.004

Brown, V., DeHayes, W. C., Hoffer, A. D., Martin, E. J., \& Perkins, C. W. (2009). Managing information technology. Upper Saddle River, NJ: Prentice Hall.

Covin, J. G., \& Slevin, D. P. (1989). Strategic management of small firms in hostile and benign environments. Strategic Management Journal, 10, 75-87. http://dx.doi.org/10.1002/smj.4250100107

Covin, J. G., \& Slevin, D. P. (Eds.). (1986). The Development and Testing of an organizational level Entrepreneurship Scale. Wellesley, MA: Babson College.

Covin, J. G., \& Wales, W. J. (2010). The Measurement of Entrepreneurial Orientation. Paper presented at the Annual Meeting of the Academy of Management (AoM), Montreal, QC.

Davenport, H. T. (1998). Putting the Enterprise into the Enterprise System. Harvard Business Review, 121-131.

Davenport, H. T. (2002). Putting the Enterprise into the Enterprise System. Harvard Business Review, 9(3), 14.

Davenport, T. H., \& Brooks, J. D. (2004). Enterprise systems and the supply chain. Journal of Enterprise Information Management, 17(1), 8-19. http://dx.doi.org/10.1108/09576050410510917

Evans, M., \& Bragg, S. (1997). Ovum Evaluates ERP for Manufacturers. Ovum' 1997 Report.

Frank, H., Kessler, A., \& Fink, M. (2010). Entrepreneurial Orientation and Business Performance-A Replication Study. Schmalenbach Business Review, 62, 175-198.

Gupta, P. M., \& Bhatia, D. (2005). Reworking with a legacy financial accounting system. Lessons from pharma 
company. Interfaces, 30(3), 4.

Huang, Z., \& Palvia, P. (2001). ERP implementation issues in advanced and developing countries. Business Process Management Journal, 7(3), 276-284. http://dx.doi.org/10.1108/14637150110392773

Hunton, J. E., Lippincott, B., \& Reck, J. L. (2003). Enterprise resource planning systems: Comparing firm performance of adopters and non-adopters. International Journal of Accounting Information Systems, 4(3), 165-184. http://dx.doi.org/10.1016/S1467-0895(03)00008-3

Irani, Z., \& Love, P. E. D. (2001). The propagation of technology management taxonomies for evaluating investments in information systems. Journal of Management Information Systems, 7(3), 161-177.

Jha, V. S., \& Joshi, H. (2007). Relevance of Total Quality Management (TQM) or business Excellence Strategy Implementation for Enterprise Resource Planning (ERP)-A Conceptual Study.

Jogaratnam, G., \& Tse, E. C. Y. (2006). Entrepreneurial orientation and the structuring of organizations: Performance evidence from the Asian hotel industry. International Journal of Contemporary Hospitality Management, 18(6), 454-468. http://dx.doi.org/10.1108/09596110610681502

Kallunki, J., Laitinen, E. K., \& Silvola, H. (2011). Impact of enterprise resource planning systems on management control systems and firm performance. International Journal of Accounting Information Systems, 12(1), 20-39. http://dx.doi.org/10.1016/j.accinf.2010.02.001

Kang, S., Park, J. H., \& Yang, H. D. (2008). ERP alignment for positive business performance: Evidence from Korea's ERP market. Journal of Computer Information Systems, 25-38.

Kaplan, R. S., \& Norton, D. P. (1992). The balanced scorecard \pm measures that drive Performance. Harvard Business Review, 70-79.

Kraus, S., Rigtering, J. O. C., Hughes, M., \& Hosman, V. (2012). Entrepreneurial orientation and the business performance of SMEs: A quantitative study from the Netherlands. Review Management Science, 6, 161-182. http://dx.doi.org/10.1007/s11846-011-0062-9

Kumar, V., Maheshwari, B., \& Kumar, U. (2002). Enterprise Resource Planning Systems Adoption Process: A Survey of Canadian Organizations. International Journal of Production Research, 40, 509-523. http://dx.doi.org/10.1080/00207540110092414

Laughlin, S. (1999). An ERP game plan. Journal of Business Strategy, 20(1), 32. http://dx.doi.org/10.1108/eb039981

Lee, M. S., Lim, S., \& Pathak, R. D. (2011). Culture and entrepreneurial orientation: A multi-country study. International of Entrepreneurship Management Journal, 7, 1-15. http://dx.doi.org/10.1007/s11365-009-0117-4

Li, H., Zhang, Y., \& Chan, T. S. (2005). Entrepreneurial Strategy Making and Performance in China's New Technology Ventures: The Contingency Effect of Environments and Firm Competences. Journal of High Technology Management Research, 16, 37-57. http://dx.doi.org/10.1016/j.hitech.2005.06.003

Lumpkin, G. T., \& Dess, G. G. (1996). Clarifying the entrepreneurial orientation (EO) construct and linking it to performance. Academic of Management Review, 21(1), 135-172.

Lumpkin, G. T., \& Dess, G. G. (2001). Linking two dimensions of entrepreneurial orientation (EO) to business performance: The moderating role of environment and industry life cycle. Journal of Business Venturing, 16, 429-451. http://dx.doi.org/10.1016/S0883-9026(00)00048-3

Mabert, V. A., Soni, A., \& Venkataramanan, M. A. (2003). Enterprise Resource Planning: Managing the implementation process. European Journal of Operation Research, 146(2), 302-314. http://dx.doi.org/10.1016/S0377-2217(02)00551-9

Madapusi, A., \& D'Souza, D. (2012a). The influence of ERP system implementation on the operational performance of an organization. International Journal of Information Management, 32(1), 24-34. http://dx.doi.org/10.1016/j.ijinfomgt.2011.06.004

Miller, D. (1983). The correlates of entrepreneurship in three types of firms. Management Science, 29, 770-791. http://dx.doi.org/10.1287/mnsc.29.7.770

Miller, D., \& Friesen, P. (1978). Archetype of strategy formulation. Management Journal, 31, 921-933.

Mische, M. A. (2002). Defining systems integration. Washington DC: Auerbach.

Møller, C. (2005). ERP II: A conceptual framework for next-generation enterprise systems? Journal of Enterprise Information Management, 18(4), 483-497. http://dx.doi.org/10.1108/17410390510609626

Motwani, J., Mirchandani, D., Madan, M., \& Gunasekaran, A. (2002). Successful implementation of ERP projects: Evidence from two case studies. International Journal of Production Economics, 75(1), 83-96. http://dx.doi.org/10.1016/S0925-5273(01)00183-9 
Murray, M., \& Coffin, G. A. (2001). Case Study Analysis of Factors for Success in ERP System Implementations. Proceedings of the Seventh Americas Conference on Information Systems, 1012-1018. Boston.

Naman, J. L., \& Slevin, D. P. (1993). Entrepreneurship and the concept of fit: A model and empirical tests. Strategic Management Journal, 14, 137-153. http://dx.doi.org/10.1002/smj.4250140205

Park, J. H., Suh, H. J., \& Yang, H. D. (2007). Perceived absorptive capacity of individual users in performance of Enterprise Resource Planning (ERP) usage: The case for Korean firms. Information \& Management, 44(1), 300-312. http://dx.doi.org/10.1016/j.im.2007.02.001

Poston, R., \& Grabski, S. (2001). Financial impacts of enterprise resource planning implementations. International Journal of Accounting 271-294. http://dx.doi.org/10.1016/S1467-0895(01)00024-0

Reilly, K. (2005). AMR research releases ERP market report showing overall market growth of $14 \%$ in 2004 . AMR Research.

Scalle, C. X., \& Cotteleer, M. J. (1994). Enterprise Resources Planning (ERP). Boston, MA: Harvard Business School Publishing.

Schumpeter, J. A. (1942). Capitalism, socialism and democracy. Harper and Brothers, New York.

Shad, S., Chen, E., \& Azeem, F. M. (2011). Performance Enhancement Factors of ERP Projects in a Telecom Public Sector Organization of Pakistan: An Exploratory Study. Interdisciplinary Journal of Contemporary Research in Business, 2(11), 95-109.

Sharma, A., \& Dave, S. (2011). Entrepreneurial orientation: Performance Level. SCMS Journal of Indian Management, 43-53.

Smart, D. T., \& Conant, J. S. (1994). Entrepreneurial orientation (EO), distinctive marketing competencies and organizational performance. Journal of Applied Business Research, 10, 28-38.

Somers, T. M., \& Nelson, K. G. (2004). A taxonomy of players and activities across the ERP project life cycle. Information \& Management, 41, 257-278. http://dx.doi.org/10.1016/S0378-7206(03)00023-5

Stratman, J. K., \& Roth, A. V. (2002). Enterprise resource planning (ERP) competence constructs: Two-stage multi-item scale development and validation. Decision Sciences, 33(4), 601-628. http://dx.doi.org/10.1111/j.1540-5915.2002.tb01658.x

Velcu, O. (2007). Exploring the effects of ERP systems on organizational performance: Evidence from Finnish companies. Industrial Management \& Data Systems, 107(9), 1316-1334. http://dx.doi.org/10.1108/02635570710833983

Walker, G. (2004). Modern competitive strategy. New York: McGraw-Hill.

Wei, C. C. (2007). Evaluating the performance of an ERP system based on the knowledge of ERP implementation objectives. The International Journal of Advanced Manufacturing Technology, 39(1-2), 168-181. http://dx.doi.org/10.1007/s00170-007-1189-3

Wieder, B., Booth, P., Matolcsy, Z. P., \& Ossimitz, M. L. (2006). The impact of ERP systems on firm and business process performance. Journal of Enterprise Information Management, 19(1), 13-29. http://dx.doi.org/10.1108/17410390610636850

Wiklund, J. (1999). The sustainability of entrepreneurial orientation (EO)-performance relationship. Entrepreneurship Theory and Practice, 24(1), 37-48.

Yang, C., Ting, P., \& Wei, C. (2006). A Study of the Factors Impacting ERP System Performance-from the Users' Perspectives. The Journal of American Academy of Business, 8(2), 161-166.

Zahra, S. (1991). Predictors and financial outcomes of corporate entrepreneurship: An explorative study. Journal of Business Venturing, 6, 259-285. http://dx.doi.org/10.1016/0883-9026(91)90019-A

Zahra, S. A., \& Covin, J. (1995). Contextual influences on the corporate entrepreneurship-performance relationship: A longitudinal analysis. Journal of Business Venturing, 10, 43-58. http://dx.doi.org/10.1016/0883-9026(94)00004-E

\section{Copyrights}

Copyright for this article is retained by the author(s), with first publication rights granted to the journal.

This is an open-access article distributed under the terms and conditions of the Creative Commons Attribution license (http://creativecommons.org/licenses/by/3.0/). 